\title{
INTEGRATION OF HUMIC ACID WITH NITROGEN WIELDS AN AUXILIARY IMPACT ON PHYSIOLOGICAL TRAITS, GROWTH AND YIELD OF MAIZE (Zea mays L.) VARIETIES
}

\author{
KHAN, S. A. ${ }^{1}-$ KHAN, S. U. ${ }^{1}-$ QAYYUM, A. ${ }^{1 *}$ - GURMANI, A. R. ${ }^{2}-$ KHAN, A. ${ }^{1}-$ KHAN, S. M. ${ }^{3}$ \\ AHMED, W. ${ }^{3}-$ MEHMOOD, A. ${ }^{2}-$ AMIN, B. A. Z. ${ }^{4}$ \\ ${ }^{I}$ Department of Agronomy, The University of Haripur, 22620 Pakistan \\ ${ }^{2}$ Department of Soil Science, The University of Haripur, 22620 Pakistan \\ ${ }^{3}$ Department of Horticulture, The University of Haripur, 22620 Pakistan \\ ${ }^{4}$ Department of Environmental Sciences, COMSATS University Islamabad, Abbottabad \\ Campus, 22060 Pakistan \\ *Corresponding author \\ e-mail:qayyum2811@gmail.com,aqayyum@uoh.edu.pk
}

(Received $10^{\text {th }}$ Feb 2019; accepted $8^{\text {th }}$ Apr 2019)

\begin{abstract}
A field experiments was conducted to investigate the soil application of humic acid and nitrogen levels at Agricultural Research Station, Swabi, Pakistan during 2014. Experimental soil was deficient in organic matter $(0.52 \%)$ and total nitrogen $(0.029 \%)$. Effect of humic acid and nitrogen levels on plant height, leaves plant ${ }^{-1}$, leaf area plant ${ }^{-1}$, leaf area index, grain yield, total $\mathrm{N}$ uptake, net assimilation rate as well as nitrate reductase activity in leaves were determined using maize variety Jalal and Iqbal. Four levels of humic acid $\left(0,0.6,1.2\right.$ and $\left.1.8 \mathrm{~kg} \mathrm{ha}^{-1}\right)$ and two levels of nitrogen $\left(0\right.$ and $\left.120 \mathrm{~kg} \mathrm{ha}^{-1}\right)$ were applied in soil along with basal fertilization of phosphorus and potassium. Nitrogen concentrations and uptake were determined from the grain and stover. All the applied levels of humic acid significantly enhanced growth and yield attributes of both maize varieties in the presence of nitrogen. However, application of 1.2 and $1.8 \mathrm{~kg} \mathrm{ha}^{-1}$ were only effective to increase growth and yield attributes in the absence of nitrogen. Soil application of nitrogen significantly increased growth and yield of both maize verities; however, it was significantly lower than all the soil applied HA levels with nitrogen. Maize variety Iqbal showed significantly higher NR activity in leaves, net assimilation rate, grain yield and harvest index than Jalal. Nitrogen concentration and uptake were significantly augmented with increasing level of humic acid in grain and stover. However, maximum total $\mathrm{N}$ uptake was recorded with the application of $1.8 \mathrm{~kg} \mathrm{ha}^{-1} \mathrm{HA}+\mathrm{N}$ in maize variety Iqbal. Among different applied HA levels, maximum grain yield was obtained from the soil application of $1.8 \mathrm{~kg} \mathrm{HA} \mathrm{ha}^{-1}$ with nitrogen in both varieties. Therefore, $1.8 \mathrm{~kg} \mathrm{ha}^{-1} \mathrm{HA}$ along with $120 \mathrm{~kg} \mathrm{~N} \mathrm{ha}^{-1}$ in maize variety Iqbal could be recommended for higher grain yield in calcareous $\mathrm{N}$ deficient soil conditions.
\end{abstract}

Keywords: grain yield, leaf area index, net assimilation rate, humic acid, nitrogen levels

\section{Introduction}

Maize is considered a major crop in Pakistan, as it occupy third most important position after wheat and rice in terms of area and grain yield (Government of Pakistan, 2016). Maize is cultivated for fodder and grain in various tropical, subtropical and temperate areas of the world; including Pakistan. Due to rapid increase in human population, horizontal increase in maize area is not possible. Therefore, the only way to increase maize productivity lies in increasing yield of existing maize genotypes through various integrated nutrient management practices (Grassini et al., 2011). Pakistani soils are mostly calcareous, alkaline and deficient in organic matter (Azam et al., 2001). Nutrients deficiencies prevail in the soil due to insufficient and poor 
nutrient management which adversely affect the yield of crops and fertility of the soil with the course of time (Afzal and Ahmad, 2009). Different management practices are applied to enhance and sustain soil fertility. For example, production of field crops had been successfully improved with the application of farm yard manure, green manure, composting and application of some organic fertilizers. Nitrogen has main role in various physiological, biochemical processes and yield traits of maize (Amanullah, 2016; Maheswari et al., 2017). Nitrogen application improves growth rate of the plants with greater leaf expansion, reduced senescence and higher dry matter accumulation (Rizwan et al., 2003). It performs a crucial role in crop production as it contributes significantly to the yield and yield components of maize crop (Sharifi and Taghizadeh, 2009). However, its scarcity is regarded as one of the major yield retarding factors because it is prone to a number of losses.

Humic acid is an organically charged bio-stimulant (Moghadam et al., 2015) made by the bacterial and chemical processes in the soil. It is an essential part of organic matter that improves physical, biological and chemical properties of the soil, for example water holding capacity, nutrient availability, soil penetrability and soil structure (Nardi et al., 2002; Khan et al., 2013). It increases organic matter, organic carbon and water retention which ultimately augment fertilizer retention in the soil (Dong et al., 2006). It has the potential to enhance various physiological and biochemical process within the plant; for example, chlorophyll, net assimilation rate, carbohydrate, leaf area and roots development (Turkmen et al., 2004; Khan et al., 2013; Traversa et al., 2014). It can diminish nitrogen losses by stimulating soil exchangeable ammonium $\left(\mathrm{NH}_{4}^{+}\right)$and available nitrate $\left(\mathrm{NO}_{3}{ }^{-}\right)$which leads towards higher nitrogen retention in the soil and uptake by the plants (Mohd et al., 2009). Therefore, adequate application of humic substances in the soil has capability to increase the availability of macro (N, P, K and $\mathrm{Ca}$ ) and micro nutrients (Fe, $\mathrm{Zn}$ and $\mathrm{Mn}$ ) as well as their uptake in the plants (Saruhan et al., 2011; Daur and Bakhashwain, 2013; Khan et al., 2013). It is important to identify maize varieties which have the ability to produce higher grain yield under the cropping systems practiced by the small land holder farmers, as very little effort has been made in this regard (Tolessa et al., 2007). Sustainable crop production depends on the continuous renewal of soil fertility through a balance between $\mathrm{N}$ demand and supply in cropping systems (Yousaf et al., 2016). There seems to be a synergistic relationship between humic acid and $\mathrm{N}$ as it has a crucial role on the fate of organic nitrogen in the soil, $\mathrm{N}$ cycling, distribution and its availability to the plants (Dong et al., 2009).

Soil of arid and semi-arid region having low precipitation and high evapotranspiration resulted in lower organic matter, nutrient deficiencies and high $\mathrm{pH}$. The beneficial effect of humic acid and nitrogen in various plant species has been well reported; however, specific effect of different levels of HA with and without nitrogen in maize has yet to be explored. In addition, we will determine the potential of humic acid to trigger net assimilation rate, nitrate reductase activity, total nitrogen uptake and grain yield in two different maize varieties under field conditions.

\section{Materials and methods}

\section{Experimental site}

The study was conducted at experimental field located at $34^{\circ} 7^{\prime} 12 \mathrm{~N}$ and $72^{\circ} 28^{\prime} 12 \mathrm{E}$ in Agricultural Research Station Swabi, Pakistan. The climate of the experimental site is subtropical, semi-arid, hot and continental with $568 \mathrm{~mm}$ annual rainfall on average basis. The average temperature of $40^{\circ} \mathrm{C}$ was recorded in the summer season, while the lower level of 
temperature was $25^{\circ} \mathrm{C}$ in the same season. Average maximum temperature during the winter months was $18.4^{\circ} \mathrm{C}$ while the minimum temperature was $4^{\circ} \mathrm{C}$.

\section{Experimental procedure}

Before starting the experiment, soil samples were collected from 0-30 cm depth at different locations of the field to determine the physico-chemical properties of soil. Soil was air dried, grinded and passed through $2 \mathrm{~mm}$ sieve to remove clods and materials other than soil. Soil characteristics were silt loam textural class with $\mathrm{pH} 7.8$, electrical conductivity $0.20 \mathrm{dS} \mathrm{m}^{-1}$, organic matter $0.52 \%$, total nitrogen $0.029 \%$, available phosphorous $5.72 \mathrm{mg} \mathrm{kg}^{-1}$, potassium $118 \mathrm{mg} \mathrm{kg}^{-1}$, zinc $2.30 \mathrm{mg} \mathrm{kg}$, copper $2.70 \mathrm{mg} \mathrm{kg}^{-1}$, iron $2.41 \mathrm{mg} \mathrm{kg}^{-1}$ and manganese $97 \mathrm{mg} \mathrm{kg}^{-1}$. Field experiment was conducted during the summer 2014 in a randomized complete block design with split plot arrangement having three replications. Factorial experiment comprised of two maize varieties Jalal and Iqbal in the main plot, while the treatments of humic acids and $\mathrm{N}$ levels were allotted to the subplots. The area of each subplot was $4.9 \mathrm{~m} \mathrm{x} 3 \mathrm{~m}\left(14.7 \mathrm{~m}^{2}\right)$. Manual method of sowing was used for planting with plant to plant distance of $20 \mathrm{~cm}$ and row to row distance of $70 \mathrm{~cm}$. Detail of treatments is given in Table 1. The Humic harvest, USA was purchased from market and used in the research study at $2000 \mathrm{ppm}(2 \mathrm{~g}$ humic acid liter $\left.^{-1}\right)$ solution from the matured dried stems and empty heads of sunflower after seed removal. Basal fertilizer of $\mathrm{P}$ and $\mathrm{K}$ was applied at 100 and $60 \mathrm{~kg} \mathrm{ha}^{-1}$ in the form of single super phosphate and sulphate of potash. Soil was prepared well for sowing of maize varieties with the help of primary and secondary tillage. The required $\mathrm{N}$ levels were applied to the subplots of maize varieties in two split applications (17 days-after-sowing (DAS) and 35 DAS. Humic acid was applied to maize varieties 14 DAS in a single application. Weeds were controlled by the application of Primextra $400 \mathrm{~mL}$ (Atrazine $223 \mathrm{~g} / \mathrm{L}+$ Metolachlor $277 \mathrm{~g} \mathrm{~L}^{-1}$ ) weedicide before pre-emergence. Five irrigations were applied to the crop at knee stage (grand growth stage), pre-tasseling, silking, dough stage and seed fill stage with the help of canal water. Various cultural practices were done all over the growing period.

Table 1. Detail of treatments is given below

\begin{tabular}{c|c}
\hline Treatments & Detail \\
\hline T1 & Control (without HA and N) \\
T2 & Soil application of $0.6 \mathrm{~kg} \mathrm{HA}+0 \mathrm{~kg} \mathrm{~N} \mathrm{ha}^{-1}$ \\
T3 & Soil application of $1.2 \mathrm{~kg} \mathrm{HA}+0 \mathrm{~kg} \mathrm{~N} \mathrm{ha}^{-1}$ \\
T4 & Soil application of $1.8 \mathrm{~kg} \mathrm{HA}+0 \mathrm{~kg} \mathrm{~N} \mathrm{ha}^{-1}$ \\
T5 & Soil application of $0 \mathrm{~kg} \mathrm{HA}+120 \mathrm{~kg} \mathrm{~N} \mathrm{ha}^{-1}$ \\
T6 & Soil application of $0.6 \mathrm{~kg} \mathrm{HA}+120 \mathrm{~kg} \mathrm{~N} \mathrm{ha}^{-1}$ \\
T7 & Soil application of $1.2 \mathrm{~kg} \mathrm{HA}+120 \mathrm{~kg} \mathrm{~N} \mathrm{ha}^{-1}$ \\
T8 & Soil application of $1.8 \mathrm{~kg} \mathrm{HA}+120 \mathrm{~kg} \mathrm{~N} \mathrm{ha}^{-1}$ \\
\hline
\end{tabular}

The data on plant height, leaves plant ${ }^{-1}$ at silking, leaf area plant $^{-1}$ at silking, leaf area index (LAI) at silking, nitrate reductase (NR) activity in leaves at 30 DAS, net assimilation rate (NAR) at 30-75 DAS, ears $\mathrm{m}^{-2}$, ears plant ${ }^{-1}$, ear length $(\mathrm{cm})$, thousand grain weight $(\mathrm{g})$, grain yield $\left(\mathrm{kg} \mathrm{ha}^{-1}\right)$, stover yield $\left(\mathrm{kg} \mathrm{ha}^{-1}\right)$, harvest index $(\%)$, grain $\mathrm{N}$ concentration (\%), stover $\mathrm{N}$ concentration (\%), grain $\mathrm{N}$ uptake $\left(\mathrm{kg} \mathrm{ha}^{-1}\right)$, stover $\mathrm{N}$ uptake $\left(\mathrm{kg} \mathrm{ha}^{-1}\right)$ and total $\mathrm{N}$ uptake $\left(\mathrm{kg} \mathrm{ha}^{-1}\right)$ were determined. For determining plant height, five maize plants were selected randomly at silking from each subplot and the average length was measured from ground level to the top of tassel by using a measuring tape. Likewise, 
at silking five maize plants were taken at random from each subplot, leaves counted and the average calculated. The leaf area $\left(\mathrm{cm}^{2}\right)$ plant $^{-1}$ was measured by multiplying average leaf area with number of leaves plant ${ }^{-1}$ and the LAI was calculated by digital hand held laser leaf area meter (CI-203 Bio- Science, USA). The enzyme nitrate reductase (NR EC 1.7.1.1) activity in leaves was measured from fresh plant tissues of three top leaves at 30 DAS and expressed as unit per mg protein (Lewis et al., 1982). One unit equivalents to the production of $1 \mu \mathrm{mol}$ of $\mathrm{NO}_{2}$ per minute at $25^{\circ} \mathrm{C}$. Net assimilation rate (30-75 DAS) was determined by dividing the total dry matter of plants by their leaf area duration (Beadle, 1993). It was expressed as $\mathrm{g} \mathrm{m}^{-2}$ day $^{-1}$.

The number of ears $\mathrm{m}^{-2}$ was calculated by dividing the number of ears by row length $(\mathrm{m}) \mathrm{x}$ r-r distance $\mathrm{x}$ number of rows. The number of ears plant $^{-1}$ was recorded by dividing the numbers of ears by the number of ears in each subplot. For ear length of maize varieties, after harvesting and dehusking, the length of five ears was recorded and averaged. At crop maturity, the two central rows were harvested manually. All the plots of the crop were bundled separately, labeled properly and brought to the threshing room. The 1000-grain weight, stover yield and grain yield were estimated with electrical balance. Likewise, the harvest index (HI) was recorded by dividing the grain yield by biological yield and then multiplying by 100 . The grain and stover $\mathrm{N}$ concentration (\%) was calculated by the Bremner and Mulvaney (1982) method, which is known as Kjeldahl method. The grain and stover $\mathrm{N}$ uptake $\left(\mathrm{kg} \mathrm{ha}^{-1}\right)$ were measured by multiplying the grain and stover $\mathrm{N}$ concentration (\%) with grain and stover yield $\left(\mathrm{kg} \mathrm{ha}^{-1}\right)$ respectively and then dividing by 100 . Furthermore, the total $\mathrm{N}$ uptake was calculated by adding the grain $\mathrm{N}$ uptake and stover $\mathrm{N}$ uptake.

\section{Statistical analysis}

Data were statistically analyzed using the analysis of variance using the method described by Steel et al. (1997), and means between treatments was compared by least significant difference $(\mathrm{P} \leq 0.05)$. All the parameters mean values were expressed as mean value with standard error (SE).

\section{Results}

\section{Plant height (cm)}

Plant height of both maize varieties were significantly increased with the combined effect of all the applied levels of humic acid with $\mathrm{N}$; however, alone application of humic acid was only significant in $1.8 \mathrm{~kg} \mathrm{ha}^{-1}$ in both varieties. The sole application of $\mathrm{N}$ substantially increased plant height of both varieties, however, it was significantly lower than the application of 1.2 and $1.8 \mathrm{~kg} \mathrm{HA}$ with $\mathrm{N}$ (Table 2). Plant height increase due to the application of 1.2 and $1.8 \mathrm{~kg} \mathrm{HA} \mathrm{ha}^{-1}$ with $\mathrm{N}$ was statistically at par with each other. Maximum plant height was recorded with the application of $1.8 \mathrm{~kg} \mathrm{HA} \mathrm{ha}^{-1}$ with $\mathrm{N}$; while the minimum was achieved with control plants in both maize varieties. Plant height of maize variety Jalal was significantly higher than Iqbal.

\section{Leaves plant ${ }^{-1}$}

The sole application of 1.2 and $1.8 \mathrm{~kg} \mathrm{HA} \mathrm{ha}^{-1}$ significantly enhanced the number of leaves plant $^{-1}$, however, any increase due to individual application of $0.6 \mathrm{Kg} \mathrm{HA} \mathrm{ha}^{-1}$ was statistically not different as compared to control in both maize varieties (Table 2). The alone effect of 1.2 
and $1.8 \mathrm{~kg} \mathrm{HA} \mathrm{ha}^{-1}$ was statistically at par with each other in terms of number of leaves plant ${ }^{1}$. Individual application of $\mathrm{N}$ and all the combined applications of HA with $\mathrm{N}$ significantly increased number of leaves plant ${ }^{-1}$ in both the maize varieties. The maximum number of leaves plant ${ }^{-1}$ was observed with the combined application of $1.8 \mathrm{~kg} \mathrm{HA} \mathrm{ha}^{-1}+\mathrm{N}$ which was at par with $1.2 \mathrm{~kg} \mathrm{HA} \mathrm{ha}^{-1}+\mathrm{N}$. Higher number of leaves plant ${ }^{-1}$ were recorded in maize variety Jalal as compared to Iqbal.

Table 2. Effect of different levels of humic acid in the absence and presence of nitrogen on plant height $(\mathrm{cm})$ and leaves plant ${ }^{-1}$ of maize variety Jalal and Iqbal

\begin{tabular}{c|cc|cc}
\hline \multirow{2}{*}{ Treatments } & \multicolumn{2}{|c|}{ Plant height $(\mathbf{c m})$} & \multicolumn{2}{c}{ Leaves plant $^{-1}$} \\
\cline { 2 - 5 } & Jalal & Iqbal & Jalal & Iqbal \\
\hline Control $\left(0 \mathrm{~kg} \mathrm{HA}+0 \mathrm{~kg} \mathrm{~N} \mathrm{ha}^{-1}\right)$ & $197.8 \pm 0.92 \mathrm{de}$ & $177.0 \pm 0.44 \mathrm{i}$ & $11.56 \pm 0.04 \mathrm{f}$ & $10.74 \pm 0.04 \mathrm{i}$ \\
$0.6 \mathrm{~kg} \mathrm{HA}+0 \mathrm{~kg} \mathrm{~N} \mathrm{ha}^{-1}$ & $199.3 \pm 0.87 \mathrm{~d}$ & $178.8 \pm 0.28 \mathrm{hi}$ & $11.72 \pm 0.05 \mathrm{ef}$ & $10.79 \pm 0.04 \mathrm{hi}$ \\
$1.2 \mathrm{~kg} \mathrm{HA}+0 \mathrm{~kg} \mathrm{~N} \mathrm{ha}^{-1}$ & $201.0 \pm 1.05 \mathrm{~cd}$ & $180.3 \pm 0.86 \mathrm{hi}$ & $11.87 \pm 0.02 \mathrm{de}$ & $10.96 \pm 0.04 \mathrm{gh}$ \\
$1.8 \mathrm{~kg} \mathrm{HA}+0 \mathrm{~kg} \mathrm{~N} \mathrm{ha}^{-1}$ & $202.6 \pm 1.19 \mathrm{c}$ & $181.7 \pm 0.80 \mathrm{~h}$ & $11.99 \pm 0.04 \mathrm{~d}$ & $11.06 \pm 0.04 \mathrm{~g}$ \\
$0 \mathrm{~kg} \mathrm{HA}+120 \mathrm{~kg} \mathrm{~N} \mathrm{ha}^{-1}$ & $207.8 \pm 0.52 \mathrm{~b}$ & $190.1 \pm 0.23 \mathrm{~g}$ & $12.45 \pm 0.04 \mathrm{c}$ & $11.57 \pm 0.02 \mathrm{f}$ \\
$0.6 \mathrm{~kg} \mathrm{HA}+120 \mathrm{~kg} \mathrm{~N} \mathrm{ha}^{-1}$ & $209.2+0.41 \mathrm{~b}$ & $192.0 \pm 0.36 \mathrm{fg}$ & $12.62+0.04 \mathrm{bc}$ & $11.74 \pm 0.04 \mathrm{ef}$ \\
$1.2 \mathrm{~kg} \mathrm{HA}+120 \mathrm{~kg} \mathrm{~N} \mathrm{ha}^{-1}$ & $210.9 \pm 0.40 \mathrm{ab}$ & $193.2 \pm 0.28 \mathrm{fg}$ & $12.83 \pm 0.04 \mathrm{ab}$ & $11.81 \pm 0.05 \mathrm{de}$ \\
$1.8 \mathrm{~kg} \mathrm{HA}+120 \mathrm{~kg} \mathrm{~N} \mathrm{ha}^{-1}$ & $213.3 \pm 0.45 \mathrm{a}$ & $194.80 \pm 0.38 \mathrm{ef}$ & $12.98 \pm 0.07 \mathrm{a}$ & $11.97 \pm 0.04 \mathrm{~d}$ \\
\hline Means & $205.2 \mathrm{a}$ & $186.0 \mathrm{~b}$ & $12.25 \mathrm{a}$ & $11.33 \mathrm{~b}$ \\
\hline
\end{tabular}

Mean followed by same letters in a column do no differ significantly at $\mathrm{P} \leq 0.05$

\section{Leaf area $\left(\mathrm{cm}^{2}\right)$ plant $^{-1}$}

Leaf area index was significantly improved with all the applied levels of humic acid, except $0.6 \mathrm{Kg} \mathrm{HA} \mathrm{ha}^{-1}$ in the absence of $\mathrm{N}$ in both maize varieties. (Table 3). The alone impact of 1.2 and $1.8 \mathrm{~kg} \mathrm{HA} \mathrm{ha}^{-1}$ on leaf area plant $^{-1}$ of both maize varieties were statistically same with each other. However, the effect of alone application of humic acid on leaf area plant ${ }^{-1}$ was lower than sole use of $\mathrm{N}$. The integrated application of all the HA levels with $\mathrm{N}$ significantly accelerated the leaf area plant ${ }^{-1}$ in both maize varieties. Maximum leaf area plant ${ }^{-1}$ was recorded with $1.8 \mathrm{Kg} \mathrm{ha}^{-1} \mathrm{HA}+\mathrm{N}$ in maize variety Jalal, while the minimum was recorded with control plants in Iqbal.

\section{Leaf area index (LAI)}

All the levels of applied humic acid in the absence and presence of nitrogen and alone application of nitrogen improved leaf area index in both maize varieties (Table 3). However, in the absence of nitrogen, $1.8 \mathrm{~kg} \mathrm{ha}^{-1}$ humic acid significantly enhanced leaf area index in both varieties. The leaf area index increase due to the individual application of $\mathrm{HA}$ at 0.6 and $1.2 \mathrm{~kg} \mathrm{HA} \mathrm{ha}^{-1}$ was at par with each other in either maize variety. The combined use of $1.8 \mathrm{~kg} \mathrm{HA} \mathrm{ha}^{-1}+\mathrm{N}$ resulted in maximum leaf area index which was at par with $1.2 \mathrm{~kg} \mathrm{HA} \mathrm{ha}^{-1}+\mathrm{N}$ in both varieties. Maize variety Jalal exhibited higher leaf area index as compared to Iqbal. Lower leaf area index was recorded in control plots of humic acid and $\mathrm{N}$.

\section{Nitrate reductase activity in leaves (unit $\mathrm{mg}^{-1}$ protein)}

Nitrate reductase (NR) activity in leaves was significantly accelerated with the increasing level of humic acid in the absence and presence of nitrogen in both maize varieties (Table 4). The sole impact of 1.2 and $1.8 \mathrm{~kg} \mathrm{HA} \mathrm{ha}^{-1}$ on NR activity of maize 
varieties was statistically at par with each other. Although, the alone application of $\mathrm{N}$ significantly increased NR activity; however, the magnitude of increase was higher under the combined use of humic acid and nitrogen. Moreover, highest NR activity was observed at $1.8 \mathrm{~kg} \mathrm{HA} \mathrm{ha}^{-1}+\mathrm{N}$ while the lowest was recorded with control plants in both varieties. The impact of $1.8 \mathrm{~kg} \mathrm{HA} \mathrm{ha}^{-1}+\mathrm{N}$ on NR activity was at par with $1.2 \mathrm{~kg} \mathrm{HA} \mathrm{ha}^{-1}$ $+\mathrm{N}$ in each variety. The average mean of Iqbal superseded the mean of Jalal variety.

Table 3. Effect of different levels of humic acid in the absence and presence of nitrogen on leaf area plant $^{-1}$ and leaf area index (LAI) of maize variety Jalal and Iqbal

\begin{tabular}{c|cc|cc}
\hline \multirow{2}{*}{ Treatments } & \multicolumn{2}{|c|}{ Leaf area $\left.\mathbf{( c m}^{\mathbf{2}}\right)$ plant } & \multicolumn{2}{c}{ Leaf area index (LAI) } \\
\cline { 2 - 5 } & Jalal & Iqbal & Jalal & Iqbal \\
\hline Control $\left(0 \mathrm{~kg} \mathrm{HA}+0 \mathrm{~kg} \mathrm{~N} \mathrm{ha}^{-1}\right)$ & $4469 \pm 38.55 \mathrm{gh}$ & $3959 \pm 28.30 \mathrm{k}$ & $3.16 \pm 0.01 \mathrm{f}$ & $2.76 \pm 0.03 \mathrm{~h}$ \\
$0.6 \mathrm{~kg} \mathrm{HA}+0 \mathrm{~kg} \mathrm{~N} \mathrm{ha}^{-1}$ & $4596 \pm 9.45 \mathrm{efg}$ & $4064 \pm 40.48 \mathrm{jk}$ & $3.18 \pm 0.03 \mathrm{ef}$ & $2.80 \pm 0.02 \mathrm{gh}$ \\
$1.2 \mathrm{~kg} \mathrm{HA}+0 \mathrm{~kg} \mathrm{~N} \mathrm{ha}^{-1}$ & $4697 \pm 31.39 \mathrm{de}$ & $4194 \pm 39.61 \mathrm{ij}$ & $3.25 \pm 0.02 \mathrm{de}$ & $2.83 \pm 0.01 \mathrm{gh}$ \\
$1.8 \mathrm{~kg} \mathrm{HA}+0 \mathrm{~kg} \mathrm{~N} \mathrm{ha}^{-1}$ & $4827 \pm 24.26 \mathrm{~d}$ & $4265 \pm 27.17 \mathrm{i}$ & $3.28 \pm 0.01 \mathrm{~d}$ & $2.86 \pm 0.01 \mathrm{~g}$ \\
$0 \mathrm{~kg} \mathrm{HA}+120 \mathrm{~kg} \mathrm{~N} \mathrm{ha}^{-1}$ & $5122 \pm 49.69 \mathrm{c}$ & $4418 \pm 33.03 \mathrm{~h}$ & $3.56 \pm 0.01 \mathrm{c}$ & $3.11 \pm 0.01 \mathrm{f}$ \\
$0.6 \mathrm{~kg} \mathrm{HA}+120 \mathrm{~kg} \mathrm{~N} \mathrm{ha}^{-1}$ & $5279 \pm 30.15 \mathrm{~b}$ & $4541 \pm 25.71 \mathrm{fgh}$ & $3.66 \pm 0.02 \mathrm{~b}$ & $3.18 \pm 0.01 \mathrm{ef}$ \\
$1.2 \mathrm{~kg} \mathrm{HA}+120 \mathrm{~kg} \mathrm{~N} \mathrm{ha}^{-1}$ & $5390 \pm 27.02 \mathrm{ab}$ & $4643 \pm 28.04 \mathrm{ef}$ & $3.75 \pm 0.02 \mathrm{ab}$ & $3.24 \pm 0.01 \mathrm{de}$ \\
$1.8 \mathrm{~kg} \mathrm{HA}+120 \mathrm{~kg} \mathrm{~N} \mathrm{ha}^{-1}$ & $5499 \pm 33.87 \mathrm{a}$ & $4729 \pm 28.06 \mathrm{de}$ & $3.82 \pm 0.02 \mathrm{a}$ & $3.30 \pm 0.02 \mathrm{~d}$ \\
\hline Means & $4985 \mathrm{a}$ & $4352 \mathrm{~b}$ & $3.46 \mathrm{a}$ & $3.01 \mathrm{~b}$ \\
\hline
\end{tabular}

Mean followed by same letters in a column do no differ significantly at $\mathrm{P} \leq 0.05$

Table 4. Effect of different levels of humic acid in the absence and presence of nitrogen on nitrate reductase activity in leaves and net assimilation rate of maize variety Jalal and Iqbal

\begin{tabular}{c|cc|cc}
\hline \multirow{2}{*}{ Treatments } & \multicolumn{2}{|c|}{$\begin{array}{c}\text { Nitrate reductase activity in leaves } \\
(30 \text { DAS) }\end{array}$} & \multicolumn{2}{c}{ Net assimilation rate (30-75 DAS) } \\
\cline { 2 - 5 } & Jalal & Iqbal & Jalal & Iqbal \\
\hline Control $\left(0 \mathrm{~kg} \mathrm{HA}+0 \mathrm{~kg} \mathrm{~N} \mathrm{ha}^{-1}\right)$ & $0.17 \pm 0.01 \mathrm{i}$ & $0.19 \pm 0.01 \mathrm{i}$ & $8.34 \pm 0.031$ & $10.30 \pm 0.06 \mathrm{~g}$ \\
$0.6 \mathrm{~kg} \mathrm{HA}+0 \mathrm{~kg} \mathrm{~N} \mathrm{ha}^{-1}$ & $0.24 \pm 0.01 \mathrm{~h}$ & $0.27 \pm 0.01 \mathrm{gh}$ & $8.50 \pm 0.07 \mathrm{k}$ & $10.38 \pm 0.02 \mathrm{fg}$ \\
$1.2 \mathrm{~kg} \mathrm{HA}+0 \mathrm{~kg} \mathrm{~N} \mathrm{ha}^{-1}$ & $0.27 \pm 0.01 \mathrm{gh}$ & $0.31 \pm 0.02 \mathrm{f}$ & $8.66 \pm 0.08 \mathrm{j}$ & $10.52 \pm 0.02 \mathrm{ef}$ \\
$1.8 \mathrm{~kg} \mathrm{HA}+0 \mathrm{~kg} \mathrm{~N} \mathrm{ha}^{-1}$ & $0.29 \pm 0.01 \mathrm{fg}$ & $0.33 \pm 0.01 \mathrm{ef}$ & $8.79 \pm 0.02 \mathrm{j}$ & $10.65 \pm 0.02 \mathrm{e}$ \\
$0 \mathrm{~kg} \mathrm{HA}+120 \mathrm{~kg} \mathrm{~N} \mathrm{ha}^{-1}$ & $0.32 \pm 0.01 \mathrm{f}$ & $0.37 \pm 0.01 \mathrm{~d}$ & $9.45 \pm 0.05 \mathrm{i}$ & $11.69 \pm 0.02 \mathrm{~d}$ \\
$0.6 \mathrm{~kg} \mathrm{HA}+120 \mathrm{~kg} \mathrm{~N} \mathrm{ha}^{-1}$ & $0.37 \pm 0.01 \mathrm{de}$ & $0.42 \pm 0.01 \mathrm{c}$ & $9.54 \pm 0.05 \mathrm{hi}$ & $11.85 \pm 0.02 \mathrm{c}$ \\
$1.2 \mathrm{~kg} \mathrm{HA}+120 \mathrm{~kg} \mathrm{~N} \mathrm{ha}^{-1}$ & $0.41 \pm 0.01 \mathrm{bc}$ & $0.46 \pm 0.01 \mathrm{ab}$ & $9.71 \pm 0.03 \mathrm{fg}$ & $12.03 \pm 0.04 \mathrm{~b}$ \\
$1.8 \mathrm{~kg} \mathrm{HA}+120 \mathrm{~kg} \mathrm{~N} \mathrm{ha}^{-1}$ & $0.45 \pm 0.01 \mathrm{~b}$ & $0.50 \pm 0.01 \mathrm{a}$ & $9.76 \pm 0.04 \mathrm{f}$ & $12.23 \pm 0.02 \mathrm{a}$ \\
\hline Means & $0.32 \mathrm{~b}$ & $0.36 \mathrm{a}$ & $9.09 \mathrm{~b}$ & $11.21 \mathrm{a}$ \\
\hline
\end{tabular}

Mean followed by same letters in a column do no differ significantly at $\mathrm{P} \leq 0.05$

\section{Net assimilation rate ( $\mathrm{g} \mathrm{m}^{-2}$ day) (30-75 DAS)}

Increasing level of applied humic acid significantly improved net assimilation rate (NAR) respectively in the absence and presence of nitrogen, except individual application of humic acid at $0.6 \mathrm{~kg} \mathrm{ha}^{-1}$ in both varieties (Table 4). Each variety showed similar net assimilation rate due to the individual application of 1.2 and $1.8 \mathrm{~kg} \mathrm{HA} \mathrm{ha}^{-1}$. The application of $1.8 \mathrm{~kg} \mathrm{HA} \mathrm{ha}^{-1}$ along with $\mathrm{N}$ showed highest net assimilation rate in both varieties. Maize variety Iqbal exhibited higher NAR than Jalal. Net assimilation rate increase due to the application of humic acid at $1.2 \mathrm{~kg} \mathrm{ha}^{-1}$ and $1.8 \mathrm{~kg} \mathrm{ha}^{-1}$ along with nitrogen was statistically at par with each other in maize variety Jalal. Likewise, net assimilation rate increase due to the alone application of nitrogen and $0.6 \mathrm{~kg} \mathrm{ha}^{-1} \mathrm{HA}+\mathrm{N}$ was statistically at par with each other in Jalal. 


\section{Ears $\boldsymbol{m}^{-2}$}

Both of the maize varieties showed a significant response for the number of ears $\mathrm{m}^{-2}$ against the applied levels of humic acid in the presence and absence of $\mathrm{N}$, except the sole application of humic acid at $0.6 \mathrm{~kg} \mathrm{ha}^{-1}$. The alone application of $\mathrm{N}$ had a significant impact on the number of ears $\mathrm{m}^{-2}$ in both maize varieties (Table 5). Individual application of humic acid at 1.2 and $1.8 \mathrm{~kg} \mathrm{ha}^{-1}$ on ears $\mathrm{m}^{-2}$ was statistically at par with each other in both the maize varieties. The highest number of ears $\mathrm{m}^{-2}$ was observed at $1.8 \mathrm{~kg} \mathrm{HA} \mathrm{ha}^{-1}$ $+\mathrm{N}$ in both varieties. The effect of $1.8 \mathrm{~kg} \mathrm{HA} \mathrm{ha}^{-1}+\mathrm{N}$ was statistically at par with $1.2 \mathrm{~kg}$ $\mathrm{HA} \mathrm{ha} \mathrm{h}^{-1}$ in Jalal regarding the number of ears $\mathrm{m}^{-2}$. The lowest number of ears $\mathrm{m}^{-2}$ was recorded in the control plots of Jalal, while the highest was achieved with Iqbal.

Table 5. Effect of different levels of humic acid in the absence and presence of nitrogen on ears $\mathrm{m}^{-2}$ and ears plant ${ }^{-1}$ of maize variety Jalal and Iqbal

\begin{tabular}{|c|c|c|c|c|}
\hline \multirow{2}{*}{ Treatments } & \multicolumn{2}{|c|}{ Ears $\mathbf{~ m}^{-2}$} & \multicolumn{2}{|c|}{ Ears plant ${ }^{-1}$} \\
\hline & Jalal & Iqbal & Jalal & Iqbal \\
\hline Control $\left(0 \mathrm{~kg} \mathrm{HA}+0 \mathrm{~kg} \mathrm{~N} \mathrm{ha}^{-1}\right)$ & $5.26 \pm 0.02 \mathrm{~h}$ & $5.47 \pm 0.01 \mathrm{fg}$ & $0.76 \pm 0.01 \mathrm{j}$ & $0.78 \pm 0.01 \mathrm{ij}$ \\
\hline $0.6 \mathrm{~kg} \mathrm{HA}+0 \mathrm{~kg} \mathrm{~N} \mathrm{ha} \mathrm{N}^{-1}$ & $5.31 \pm 0.02 \mathrm{hi}$ & $5.53 \pm 0.02$ ef & $0.78 \pm 0.01 \mathrm{hj}$ & $0.80 \pm 0.01 \mathrm{ghi}$ \\
\hline $1.2 \mathrm{~kg} \mathrm{HA}+0 \mathrm{~kg} \mathrm{~N} \mathrm{ha}^{-1}$ & $5.38 \pm 0.01 \mathrm{gh}$ & $5.65 \pm 0.01 \mathrm{de}$ & $0.79 \pm 0.01 \mathrm{hi}$ & $0.82 \pm 0.01 \mathrm{fg}$ \\
\hline $1.8 \mathrm{~kg} \mathrm{HA}+0 \mathrm{~kg} \mathrm{~N} \mathrm{ha}^{-1}$ & $5.46 \pm 0.02 \mathrm{fg}$ & $5.70 \pm 0.02 \mathrm{~d}$ & $0.82 \pm 0.01 \mathrm{~g}$ & $0.85 \pm 0.01 \mathrm{e}$ \\
\hline $0 \mathrm{~kg} \mathrm{HA}+120 \mathrm{~kg} \mathrm{~N} \mathrm{ha}^{-1}$ & $5.75 \pm 0.05 \mathrm{~d}$ & $5.95 \pm 0.04 \mathrm{c}$ & $0.86 \pm 0.01 \mathrm{de}$ & $0.89 \pm 0.01 \mathrm{~cd}$ \\
\hline $0.6 \mathrm{~kg} \mathrm{HA}+120 \mathrm{~kg} \mathrm{~N} \mathrm{ha}^{-1}$ & $5.98+0.03 \mathrm{c}$ & $6.11 \pm 0.01 \mathrm{~b}$ & $0.88 \pm 0.01 \mathrm{~d}$ & $0.91 \pm 0.01 \mathrm{c}$ \\
\hline $1.2 \mathrm{~kg} \mathrm{HA}+120 \mathrm{~kg} \mathrm{~N} \mathrm{ha}^{-1}$ & $6.04 \pm 0.03 \mathrm{bc}$ & $6.16 \pm 0.03 \mathrm{~b}$ & $0.91 \pm 0.01 \mathrm{bc}$ & $0.94 \pm 0.01 \mathrm{ab}$ \\
\hline $1.8 \mathrm{~kg} \mathrm{HA}+120 \mathrm{~kg} \mathrm{~N} \mathrm{ha}^{-1}$ & $6.15 \pm 0.04 \mathrm{~b}$ & $6.33 \pm 0.03 \mathrm{a}$ & $0.94 \pm 0.01 \mathrm{ab}$ & $0.97 \pm 0.01 \mathrm{a}$ \\
\hline Means & $5.67 \mathrm{~b}$ & $5.86 \mathrm{a}$ & $0.84 \mathrm{~b}$ & $0.87 \mathrm{a}$ \\
\hline
\end{tabular}

Mean followed by same letters in a column do no differ significantly at $\mathrm{P} \leq 0.05$

\section{Ears plant ${ }^{-1}$}

The application of humic acid in the presence and absence of $\mathrm{N}$, as well as the alone application of $\mathrm{N}$ significantly influenced the number of ears plant ${ }^{-1}$ in both the maize varieties of Jalal and Iqbal. However, the alone application of $0.6 \mathrm{~kg} \mathrm{HA} \mathrm{ha}^{-1}$ did not cause any significant increase in the number of ears plant ${ }^{-1}$ (Table 5). The sole application of humic acid at $1.8 \mathrm{~kg} \mathrm{HA} \mathrm{ha}^{-1}$ produced the highest number of ears palnt ${ }^{-1}$. Though the sole application of $\mathrm{N}$ enhanced the ear bearing capacity of maize varieties, but the maximum number of ears plant ${ }^{-1}$ was recorded with $1.8 \mathrm{~kg} \mathrm{HA} \mathrm{ha}^{-1}+\mathrm{N}$. The minimum number of ears plant ${ }^{-1}$ was observed in the control plots. The higher number of ears plant ${ }^{-1}$ was measured in Iqbal variety of maize as compared with Jalal.

\section{Ear length (cm)}

The ear length of both maize varieties exhibited a significant response to the sole application of $\mathrm{N}$ as well as all the applied levels of humic acid with and without $\mathrm{N}$, except the alone application of humic acid at $0.6 \mathrm{~kg} \mathrm{ha}^{-1}$ (Table 5). The alone impact of 1.2 and $1.8 \mathrm{~kg} \mathrm{HA} \mathrm{ha}^{-1}$ on ear length of maize variety Jalal was statistically at par with each other. The maximum ear length was recorded with the combined use of $1.8 \mathrm{~kg} \mathrm{HA} \mathrm{ha}^{-1}+\mathrm{N}$, although the sole use of $\mathrm{N}$ also had a significant impact on the bulk of increase in each variety. The effect $1.8 \mathrm{HA} \mathrm{ha}^{-1}+\mathrm{N}$ and $1.2 \mathrm{~kg} \mathrm{HA} \mathrm{ha}^{-1}+\mathrm{N}$ on ear length of each variety was statistically at par with each other in both varieties. The minimum ear length was measured in control plots of both varieties. The mean average of ear length of Iqbal was significantly higher than Jalal variety of maize. 


\section{Thousand grain weight (g)}

The individual application of humic acid and $\mathrm{N}$ as well as their integrations had a substantial influence on thousand grain weight of maize variety Jalal and Iqbal (Table 6). Under the sole application of humic acid, the plots treated with $1.8 \mathrm{~kg} \mathrm{HA} \mathrm{ha}^{-1}$ produced highest thousand grain weight in both maize varieties. The individual effect of 0.6 and 1.2 $\mathrm{kg} \mathrm{HA} \mathrm{ha}{ }^{-1}$ was statistically at par with each other in both varieties. The highest thousand grain weight was recorded in plots supplied with $1.8 \mathrm{~kg} \mathrm{HA} \mathrm{ha}^{-1}+\mathrm{N}$ in Iqbal while the lowest was recorded in control plots of Jalal. Furthermore, the plots treated with sole $\mathrm{N}$ and $0.6 \mathrm{~kg} \mathrm{HA} \mathrm{ha}{ }^{-1}+\mathrm{N}$ produced the same thousand grain weight in Jalal.

Table 6. Effect of different levels of humic acid in the absence and presence of nitrogen on ear length $(\mathrm{cm})$ and thousand grain weight $(\mathrm{g})$ of maize variety Jalal and Iqbal

\begin{tabular}{|c|c|c|c|c|}
\hline \multirow{2}{*}{ Treatments } & \multicolumn{2}{|c|}{ Ear length $(\mathrm{cm})$} & \multicolumn{2}{|c|}{ Thousand grain weight (g) } \\
\hline & Jalal & Iqbal & Jalal & Iqbal \\
\hline Control $\left(0 \mathrm{~kg} \mathrm{HA}+0 \mathrm{~kg} \mathrm{~N} \mathrm{ha}^{-1}\right)$ & $14.30 \pm 0.04 \mathrm{k}$ & $15.22 \pm 0.03 \mathrm{i}$ & $179.9 \pm 0.95 \mathrm{k}$ & $192.6 \pm 0.47 \mathrm{gh}$ \\
\hline $0.6 \mathrm{~kg} \mathrm{HA}+0 \mathrm{~kg} \mathrm{~N} \mathrm{ha}^{-1}$ & $14.46 \pm 0.05 \mathrm{jk}$ & $15.37 \pm 0.04 \mathrm{hi}$ & $183.4 \pm 0.32 \mathrm{j}$ & $195.5 \pm 0.55$ ef \\
\hline $1.2 \mathrm{~kg} \mathrm{HA}+0 \mathrm{~kg} \mathrm{~N} \mathrm{ha}^{-1}$ & $14.70 \pm 0.04 \mathrm{i}$ & $15.56 \pm 0.02 \mathrm{gh}$ & $185.2 \pm 0.23 \mathrm{j}$ & $197.3 \pm 0.49 \mathrm{de}$ \\
\hline $1.8 \mathrm{~kg} \mathrm{HA}+0 \mathrm{~kg} \mathrm{~N} \mathrm{ha}^{-1}$ & $14.90 \pm 0.01 \mathrm{hi}$ & $15.82 \pm 0.03$ ef & $187.5 \pm 0.38 \mathrm{i}$ & $199.7 \pm 0.38 \mathrm{~d}$ \\
\hline $0 \mathrm{~kg} \mathrm{HA}+120 \mathrm{~kg} \mathrm{~N} \mathrm{ha}^{-1}$ & $15.84 \pm 0.04 \mathrm{~g}$ & $17.14 \pm 0.04 \mathrm{~d}$ & $191.8 \pm 1.04 \mathrm{~h}$ & $204.1 \pm 0.94 \mathrm{c}$ \\
\hline $0.6 \mathrm{~kg} \mathrm{HA}+120 \mathrm{~kg} \mathrm{~N} \mathrm{ha}^{-1}$ & $16.07+0.01 \mathrm{f}$ & $17.36 \pm 0.03 \mathrm{c}$ & $194.3 \pm 0.75 \mathrm{fg}$ & $206.5 \pm 0.42 \mathrm{c}$ \\
\hline $1.2 \mathrm{~kg} \mathrm{HA}+120 \mathrm{~kg} \mathrm{~N} \mathrm{ha}^{-1}$ & $16.31 \pm 0.03 \mathrm{de}$ & $17.65 \pm 0.07 \mathrm{ab}$ & $197.1 \pm 0.55 \mathrm{e}$ & $209.4 \pm 0.60 \mathrm{~b}$ \\
\hline $1.8 \mathrm{~kg} \mathrm{HA}+120 \mathrm{~kg} \mathrm{~N} \mathrm{ha}^{-1}$ & $16.51 \pm 0.03 \mathrm{~d}$ & $17.7 \underline{\underline{6}}+0.05 \mathrm{a}$ & $199.4 \pm 0.51 \mathrm{~d}$ & $212.9 \pm 0.97 \mathrm{a}$ \\
\hline Means & $15.39 \mathrm{~b}$ & $16.48 \mathrm{a}$ & $189.8 \mathrm{~b}$ & $202.2 \mathrm{a}$ \\
\hline
\end{tabular}

Mean followed by same letters in a column do no differ significantly at $\mathrm{P} \leq 0.05$

\section{Grain yield ( $\left.\mathrm{kg} \mathrm{ha}^{-1}\right)$}

The grain yield of both varieties was substantially enhanced with the increasing levels of humic acid, nitrogen as well as their combined application (Table 7). Under the alone application of humic acid, $1.8 \mathrm{~kg} \mathrm{HA} \mathrm{ha}{ }^{-1}$ resulted in higher grain yield in each variety. The application of humic acid at $1.8 \mathrm{~kg} \mathrm{ha}^{-1}$ with $\mathrm{N}$, produced the plants with the highest grain yield in both the maize varieties. The impact of $1.8 \mathrm{HA} \mathrm{ha}^{-1}+\mathrm{N}$ and $1.2 \mathrm{~kg} \mathrm{HA} \mathrm{ha}^{-1}$ $+\mathrm{N}$ on grain yield of both varieties was statistically at par with each other. The highest grain yield was achieved in plots of Iqbal treated with $1.8 \mathrm{~kg} \mathrm{HA} \mathrm{ha}^{-1}+\mathrm{N}$ while the lowest was recorded in control plots of Jalal.

Table 7. Effect of different levels of humic acid in the absence and presence of nitrogen on grain yield $\left(\mathrm{kg} \mathrm{ha}^{-1}\right)$ and stover yield $\left(\mathrm{kg} \mathrm{ha}^{-1}\right)$ of maize variety Jalal and Iqbal

\begin{tabular}{|c|c|c|c|c|}
\hline \multirow{2}{*}{ Treatments } & \multicolumn{2}{|c|}{ Grain yield (kg ha-1) } & \multicolumn{2}{|c|}{ Stover yield $\left(\mathrm{kg} \mathrm{ha}^{-1}\right)$} \\
\hline & Jalal & Iqbal & Jalal & Iqbal \\
\hline Control $\left(0 \mathrm{~kg} \mathrm{HA}+0 \mathrm{~kg} \mathrm{~N} \mathrm{ha}^{-1}\right)$ & $2540 \pm 21.651$ & $2937 \pm 7.88 \mathrm{k}$ & $7648 \pm 23.41 \mathrm{~h}$ & $6847 \pm 47.94 \mathrm{j}$ \\
\hline $0.6 \mathrm{~kg} \mathrm{HA}+0 \mathrm{~kg} \mathrm{~N} \mathrm{ha-1}$ & $3066 \pm 4.37 \mathrm{j}$ & $3209 \pm 20.43 \mathrm{i}$ & $8298 \pm 21.73 \mathrm{e}$ & $7031 \pm 42.04 \mathrm{i}$ \\
\hline $1.2 \mathrm{~kg} \mathrm{HA}+0 \mathrm{~kg} \mathrm{~N} \mathrm{ha}^{-1}$ & $3224 \pm 20.46 \mathrm{i}$ & $3328 \pm 31.12 \mathrm{~h}$ & $8485 \pm 37.29 \mathrm{e}$ & $7084 \pm 71.96 \mathrm{i}$ \\
\hline $1.8 \mathrm{~kg} \mathrm{HA}+0 \mathrm{~kg} \mathrm{~N} \mathrm{ha}^{-1}$ & $3385 \pm 14.97 \mathrm{~h}$ & $3517 \pm 23.81 \mathrm{~g}$ & $8751 \pm 53.13 \mathrm{~d}$ & $7303 \pm 17.36 \mathrm{~h}$ \\
\hline $0 \mathrm{~kg} \mathrm{HA}+120 \mathrm{~kg} \mathrm{~N} \mathrm{ha}^{-1}$ & $3942 \pm 19.19 \mathrm{f}$ & $4064 \pm 32.32 \mathrm{e}$ & $9115 \pm 43.37 \mathrm{c}$ & $7605 \pm 44.55 \mathrm{~g}$ \\
\hline $0.6 \mathrm{~kg} \mathrm{HA}+120 \mathrm{~kg} \mathrm{~N} \mathrm{ha}^{-1}$ & $4192 \pm 27.22 \mathrm{~d}$ & $4312 \pm 23.38 \mathrm{c}$ & $9367 \pm 15.13 \mathrm{~b}$ & $7778 \pm 33.74 \mathrm{fg}$ \\
\hline $1.2 \mathrm{~kg} \mathrm{HA}+120 \mathrm{~kg} \mathrm{~N} \mathrm{ha}^{-1}$ & $4465 \pm 31.65 b$ & $4564 \pm 19.40 \mathrm{~b}$ & $9542 \pm 23.07 \mathrm{ab}$ & $7851 \pm 22.98 \mathrm{ef}$ \\
\hline $1.8 \mathrm{~kg} \mathrm{HA}+120 \mathrm{~kg} \mathrm{~N} \mathrm{ha}^{-1}$ & $4742 \pm 9.53 \mathrm{a}$ & $4817 \pm 17.95 \mathrm{a}$ & $9623 \pm 62.44 \mathrm{a}$ & $8012 \pm 25.10 \mathrm{e}$ \\
\hline Means & $3694 \mathrm{~b}$ & $3844 \mathrm{a}$ & $8854 \mathrm{a}$ & $7439 \mathrm{~b}$ \\
\hline
\end{tabular}

Mean followed by same letters in a column do no differ significantly at $\mathrm{P} \leq 0.05$ 


\section{Stover yield ( $\left.\mathrm{kg} \mathrm{ha}^{-1}\right)$}

Stover yield of both maize varieties were significantly increased with the combined application of humic acid $+\mathrm{N}$ as well as under the alone application of humic acid and $\mathrm{N}$ (Table 7). The alone effect of 0.6 and $1.2 \mathrm{~kg} \mathrm{HA} \mathrm{ha}^{-1}$ on stover yield of both varieties was statistically at par with each other. Though the sole application of $\mathrm{N}$ improved stover yield of maize varieties but the maximum response was observed at $1.8 \mathrm{~kg} \mathrm{HA} \mathrm{ha}^{-1}+\mathrm{N}$ which was at par with $1.2 \mathrm{~kg} \mathrm{HA} \mathrm{ha}{ }^{-1}+\mathrm{N}$. The Jalal variety of maize exhibited highest stover yield than Iqbal. In Iqbal variety of maize, the individual effect of $\mathrm{N}$ was similar with the combined effect of $0.6 \mathrm{~kg} \mathrm{HA} \mathrm{ha}^{-1}+\mathrm{N}$.

\section{Harvest index (\%)}

The integration of humic acid and nitrogen as well as their alone applications considerably affected the harvest index of both maize varieties. The individual effect of 0.6 and $1.2 \mathrm{~kg} \mathrm{HA} \mathrm{ha}^{-1}$ on harvest index was statistically at par with $1.8 \mathrm{~kg} \mathrm{HA} \mathrm{ha}^{-1}$ in both varieties (Table 8). Maximum harvest index was recorded at $1.8 \mathrm{~kg} \mathrm{HA} \mathrm{ha}^{-1}+\mathrm{N}$ in each variety of maize. However, the impact of $1.8 \mathrm{~kg} \mathrm{HA} \mathrm{ha}^{-1}+\mathrm{N}$ was similar with $1.2 \mathrm{~kg} \mathrm{HA} \mathrm{ha}{ }^{-1}+\mathrm{N}$ in both the varieties. Moreover, in Jalal variety of maize the integrated impact of $0.6 \mathrm{~kg} \mathrm{HA} \mathrm{ha}{ }^{-1}+\mathrm{N}$ were found to be at par with individual application of $\mathrm{N}$ in terms of harvest index. The Iqbal variety of maize exhibited higher harvest index than Jalal.

Table 8. Effect of different levels of humic acid in the absence and presence of nitrogen on harvest index (\%) and grain $N$ concentration (\%) of maize variety Jalal and Iqbal

\begin{tabular}{|c|c|c|c|c|}
\hline \multirow{2}{*}{ Treatments } & \multicolumn{2}{|c|}{ Harvest index $(\%)$} & \multicolumn{2}{|c|}{ Grain $N$ concentration $(\%)$} \\
\hline & Jalal & Iqbal & Jalal & Iqbal \\
\hline Control $\left(0 \mathrm{~kg} \mathrm{HA}+0 \mathrm{~kg} \mathrm{~N} \mathrm{ha}^{-1}\right)$ & $24.93 \pm 0.14 \mathrm{j}$ & $29.72 \pm 0.18 \mathrm{~h}$ & $1.27 \pm 0.01 \mathrm{j}$ & $1.31 \pm 0.02 \mathrm{i}$ \\
\hline $0.6 \mathrm{~kg} \mathrm{HA}+0 \mathrm{~kg} \mathrm{~N} \mathrm{ha}^{-1}$ & $26.97 \pm 0.06 \mathrm{i}$ & $31.34 \pm 0.19$ ef & $1.32 \pm 0.01 \mathrm{i}$ & $1.36 \pm 0.01 \mathrm{~h}$ \\
\hline $1.2 \mathrm{~kg} \mathrm{HA}+0 \mathrm{~kg} \mathrm{~N} \mathrm{ha}^{-1}$ & $27.53 \pm 0.16 \mathrm{i}$ & $31.97 \pm 0.42 \mathrm{de}$ & $1.40 \pm 0.01 \mathrm{~g}$ & $1.42 \pm 0.01 \mathrm{fg}$ \\
\hline $1.8 \mathrm{~kg} \mathrm{HA}+0 \mathrm{~kg} \mathrm{~N} \mathrm{ha}^{-1}$ & $27.88 \pm 0.20 \mathrm{i}$ & $32.49 \pm 0.10$ cde & $1.43 \pm 0.01 \mathrm{efg}$ & $1.46 \pm 0.01 \mathrm{def}$ \\
\hline $0 \mathrm{~kg} \mathrm{HA}+120 \mathrm{~kg} \mathrm{~N} \mathrm{ha}^{-1}$ & $30.19 \pm 0.10 \mathrm{gh}$ & $34.82 \pm 0.20 \mathrm{c}$ & $1.44 \pm 0.01 \mathrm{efg}$ & $1.47 \pm 0.01 \mathrm{cde}$ \\
\hline $0.6 \mathrm{~kg} \mathrm{HA}+120 \mathrm{~kg} \mathrm{~N} \mathrm{ha}^{-1}$ & $30.92 \pm 0.15 \mathrm{fg}$ & $35.67 \pm 0.04 \mathrm{~b}$ & $1.47 \pm 0.01 \mathrm{~cd}$ & $1.50 \pm 0.01 \mathrm{bc}$ \\
\hline $1.2 \mathrm{~kg} \mathrm{HA}+120 \mathrm{~kg} \mathrm{~N} \mathrm{ha}^{-1}$ & $31.89 \pm 0.11 \mathrm{de}$ & $36.76 \pm 0.05 \mathrm{a}$ & $1.48 \pm 0.01 \mathrm{~cd}$ & $1.53 \pm 0.01 \mathrm{~b}$ \\
\hline $1.8 \mathrm{~kg} \mathrm{HA}+120 \mathrm{~kg} \mathrm{~N} \mathrm{ha}^{-1}$ & $33.01 \pm 0.19 \mathrm{c}$ & $37.55 \pm 0.05 \mathrm{a}$ & $1.53 \pm 0.01 \mathrm{~b}$ & $1.57 \pm 0.01 \mathrm{a}$ \\
\hline Means & $29.16 \mathrm{~b}$ & $33.79 \mathrm{a}$ & $1.41 \mathrm{~b}$ & $1.45 \mathrm{a}$ \\
\hline
\end{tabular}

Mean followed by same letters in a column do no differ significantly at $\mathrm{P} \leq 0.05$

\section{Grain N concentration (\%)}

The response of maize varieties Jalal and Iqbal for grain $\mathrm{N}$ concentration was found to be significant against all the applied levels of humic acid, nitrogen and their combination. However, the effect of sole application of 1.2 and $1.8 \mathrm{~kg} \mathrm{HA} \mathrm{ha}^{-1}$ on grain $\mathrm{N}$ concentration was statistically at par with each other in both the varieties (Table 8). Likewise, the impact of alone application of $\mathrm{N}$ and $1.8 \mathrm{~kg} \mathrm{HA} \mathrm{ha}^{-1}$ on grain $\mathrm{N}$ concentration was statistically not different from each other in either of the maize variety. In both varieties, the combined application of $1.8 \mathrm{~kg} \mathrm{HA} \mathrm{ha}{ }^{-1}+\mathrm{N}$ produced the plants with the highest grain $\mathrm{N}$ concentration. Furthermore, the grain $\mathrm{N}$ concentration of maize variety Iqbal were higher than Jalal. The control plots of maize varieties resulted in lower grain $\mathrm{N}$ concentration. 


\section{Stover $N$ concentration (\%)}

The different application levels of humic acid in the absence and presence of nitrogen as well as the sole application of $\mathrm{N}$ substantially enhanced the stover $\mathrm{N}$ concentration of maize varieties Jalal and Iqbal, except the alone application of humic acid at $0.6 \mathrm{~kg} \mathrm{ha}^{-1}$ (Table 9). Humic acid application at $1.8 \mathrm{~kg} \mathrm{HA} \mathrm{ha}^{-1}$ produced the highest stover $\mathrm{N}$ concentration in both varieties which was at par with $1.2 \mathrm{~kg} \mathrm{HA} \mathrm{ha}^{-1}$ and the individual application of $\mathrm{N}$. Although, the alone $\mathrm{N}$ accelerated the grain $\mathrm{N}$ concentration of both varieties but the maximum $\mathrm{N}$ concentration was recorded at $1.8 \mathrm{~kg} \mathrm{HA} \mathrm{ha}^{-1}+\mathrm{N}$ which was statistically at par with $1.2 \mathrm{~kg} \mathrm{HA} \mathrm{ha}^{-1}+\mathrm{N}$. The higher stover $\mathrm{N}$ concentration was observed in the maize variety Jalal as compared to Iqbal. The plants of control plots were studied to be lower in the stover $\mathrm{N}$ concentration in both the maize varieties.

Table 9. Effect of different levels of humic acid in the absence and presence of nitrogen on stover $\mathrm{N}$ concentration (\%) and grain $\mathrm{N}$ uptake $\left(\mathrm{kg} \mathrm{ha}^{-1}\right)$ of maize variety Jalal and Iqbal

\begin{tabular}{c|cc|cc}
\hline \multirow{2}{*}{ Treatments } & \multicolumn{2}{|c|}{ Stover N concentration $(\%)$} & \multicolumn{2}{c}{ Grain N uptake (kg ha-1) } \\
\cline { 2 - 5 } & Jalal & Iqbal & Jalal & Iqbal \\
\hline $0 \mathrm{~kg} \mathrm{HA}^{-1} 0 \mathrm{~kg} \mathrm{~N} \mathrm{ha}^{-1}$ & $0.24 \pm 0.01 \mathrm{j}$ & $0.27 \pm 0.01 \mathrm{hij}$ & $32.30 \pm 0.20 \mathrm{l}$ & $38.87 \pm 0.16 \mathrm{k}$ \\
$0.6 \mathrm{~kg} \mathrm{HA}+0 \mathrm{~kg} \mathrm{~N} \mathrm{ha}^{-1}$ & $0.26 \pm 0.01 \mathrm{ij}$ & $0.29 \pm 0.01 \mathrm{fg}-\mathrm{i}$ & $40.42 \pm 0.25 \mathrm{k}$ & $43.49 \pm 0.46 \mathrm{j}$ \\
$1.2 \mathrm{~kg} \mathrm{HA}+0 \mathrm{~kg} \mathrm{~N} \mathrm{ha}^{-1}$ & $0.28 \pm 0.01 \mathrm{ghi}$ & $0.31 \pm 0.01 \mathrm{de}-\mathrm{g}$ & $45.26 \pm 0.20 \mathrm{ij}$ & $47.15 \pm 0.34 \mathrm{hi}$ \\
$1.8 \mathrm{~kg} \mathrm{HA}+0 \mathrm{~kg} \mathrm{~N} \mathrm{ha}^{-1}$ & $0.30 \pm 0.01 \mathrm{ef}-\mathrm{h}$ & $0.33 \pm 0.01 \mathrm{cde}$ & $48.52 \pm 0.39 \mathrm{~h}$ & $51.23 \pm 0.56 \mathrm{~g}$ \\
$0 \mathrm{~kg} \mathrm{HA}+120 \mathrm{~kg} \mathrm{~N} \mathrm{ha}^{-1}$ & $0.31 \pm 0.01 \mathrm{def}$ & $0.35 \pm 0.01 \mathrm{bc}$ & $56.59 \pm 0.51 \mathrm{f}$ & $59.72 \pm 0.45 \mathrm{e}$ \\
$0.6 \mathrm{~kg} \mathrm{HA}+120 \mathrm{~kg} \mathrm{~N} \mathrm{ha}^{-1}$ & $0.33 \pm 0.01 \mathrm{~cd}$ & $0.37 \pm 0.01 \mathrm{~b}$ & $61.43 \pm 0.65 \mathrm{e}$ & $64.66 \pm 0.72 \mathrm{~d}$ \\
$1.2 \mathrm{~kg} \mathrm{HA}+120 \mathrm{~kg} \mathrm{~N} \mathrm{ha}^{-1}$ & $0.35 \pm 0.01 \mathrm{bc}$ & $0.41 \pm 0.01 \mathrm{a}$ & $66.22 \pm 0.73 \mathrm{~d}$ & $69.79 \pm 0.32 \mathrm{c}$ \\
$1.8 \mathrm{~kg} \mathrm{HA}+120 \mathrm{~kg} \mathrm{~N} \mathrm{ha}^{-1}$ & $0.37 \pm 0.01 \mathrm{~b}$ & $0.44 \pm 0.02 \mathrm{a}$ & $72.55 \pm 0.31 \mathrm{~b}$ & $75.73 \pm 0.54 \mathrm{a}$ \\
\hline Means & $0.30 \mathrm{~b}$ & $0.35 \mathrm{a}$ & $52.91 \mathrm{~b}$ & $56.33 \mathrm{a}$ \\
\hline
\end{tabular}

Mean followed by same letters in a column do no differ significantly at $\mathrm{P} \leq 0.05$

\section{Grain N uptake (kg ha-1)}

In both the maize varieties the grain $\mathrm{N}$ uptake were significantly affected by the alone application of humic acid, nitrogen as well as their integration (Table 9). Although the sole use of $\mathrm{N}$ fertilizer enhanced the grain $\mathrm{N}$ uptake of each variety, but the maximum $\mathrm{N}$ uptake was observed at $1.8 \mathrm{~kg} \mathrm{HA} \mathrm{ha}^{-1}+\mathrm{N}$. The minimum grain uptake of maize varieties was observed in the control plots of humic acid and nitrogen. The plants of Iqbal variety showed the highest grain $\mathrm{N}$ uptake when they were compared with the maize plants of Jalal variety.

\section{Stover $\mathrm{N}$ uptake $\left(\mathrm{kg} \mathrm{ha}^{-1}\right)$}

The sole application of $\mathrm{N}$ as well as the applied levels of humic acid in combination with $\mathrm{N}$ and without $\mathrm{N}$ substantially influenced the stover $\mathrm{N}$ uptake of both maize varieties, except at $0.6 \mathrm{~kg} \mathrm{ha}^{-1}$ in Iqbal (Table 10). However, under the alone application of humic acid, $1.8 \mathrm{~kg} \mathrm{HA} \mathrm{ha}^{-1}$ resulted in higher stover $\mathrm{N}$ uptake which was statistically at par with $1.2 \mathrm{~kg} \mathrm{HA} \mathrm{ha}^{-1}$ in both varieties. The sole use of $\mathrm{N}$ significantly increased the stover $\mathrm{N}$ uptake in both maize varieties. Moreover, the integrated application of $1.8 \mathrm{~kg} \mathrm{HA} \mathrm{ha}^{-1}+$ $\mathrm{N}$ produced the highest stover $\mathrm{N}$ uptake in both varieties which was statistically at par with $1.2 \mathrm{~kg} \mathrm{HA} \mathrm{ha}{ }^{-1}+\mathrm{N}$. The higher average mean of stover $\mathrm{N}$ uptake was recorded in the maize variety Jalal than Iqbal. 


\section{Total $\mathrm{N}$ uptake $\left(\mathrm{kg} \mathrm{ha}^{-1}\right)$}

The total $\mathrm{N}$ uptake of both maize varieties had significant response to the alone application of $\mathrm{N}$ as well as applied levels of humic acid in the presence and absence of $\mathrm{N}$ (Table 10). As far as the sole application of humic acid is concerned, $1.8 \mathrm{~kg} \mathrm{HA} \mathrm{ha}^{-1}$ resulted in maximum uptake of $\mathrm{N}$ in both the varieties. Likewise, the alone application of $\mathrm{N}$ increased the total $\mathrm{N}$ uptake in both maize varieties but the maximum response was observed under the combined application at $1.8 \mathrm{~kg} \mathrm{HA} \mathrm{ha}^{-1}+\mathrm{N}$. The total $\mathrm{N}$ uptake was lower in control plots of humic acid and $\mathrm{N}$ as compared with other treatments. The Iqbal variety of maize exhibited higher total $\mathrm{N}$ uptake than Jalal.

Table 10. Effect of different levels of humic acid in the absence and presence of nitrogen on stover $N$ uptake $\left(\mathrm{kg} \mathrm{ha}^{-1}\right)$ and total $N$ uptake $\left(\mathrm{kg} \mathrm{ha}^{-1}\right)$ of maize variety Jalal and Iqbal

\begin{tabular}{c|cc|cc}
\hline \multirow{2}{*}{ Treatments } & \multicolumn{2}{|c|}{ Stover N uptake $\left(\mathbf{k g ~ h a}^{-1}\right)$} & \multicolumn{2}{c}{ Total N uptake $\left(\mathbf{k g ~ h a}^{-\mathbf{1}}\right)$} \\
\cline { 2 - 5 } & \multicolumn{2}{|c|}{ Jalal } & Iqbal & \multicolumn{2}{c}{ Jalal } & Iqbal \\
\hline $0 \mathrm{~kg} \mathrm{HA}+0 \mathrm{~kg} \mathrm{~N} \mathrm{ha}^{-1}$ & $18.35 \pm 0.38 \mathrm{k}$ & $18.49 \pm 0.46 \mathrm{k}$ & $50.65 \pm 0.23 \mathrm{i}$ & $57.36 \pm 0.62 \mathrm{~h}$ \\
$0.6 \mathrm{~kg} \mathrm{HA}+0 \mathrm{~kg} \mathrm{~N} \mathrm{ha}^{-1}$ & $21.58 \pm 0.45 \mathrm{ij}$ & $20.39 \pm 0.52 \mathrm{jk}$ & $62.00 \pm 0.49 \mathrm{~g}$ & $63.88 \pm 0.59 \mathrm{~g}$ \\
$1.2 \mathrm{~kg} \mathrm{HA}+0 \mathrm{~kg} \mathrm{~N} \mathrm{ha}^{-1}$ & $23.76 \pm 0.43 \mathrm{hi}$ & $21.96 \pm 0.49 \mathrm{ij}$ & $69.02 \pm 0.53 \mathrm{f}$ & $69.11 \pm 0.25 \mathrm{f}$ \\
$1.8 \mathrm{~kg} \mathrm{HA}+0 \mathrm{~kg} \mathrm{~N} \mathrm{ha}^{-1}$ & $25.96 \pm 0.60 \mathrm{gh}$ & $23.86 \pm 0.55 \mathrm{ghi}$ & $74.48 \pm 0.55 \mathrm{e}$ & $75.09 \pm 1.01 \mathrm{e}$ \\
$0 \mathrm{~kg} \mathrm{HA}+120 \mathrm{~kg} \mathrm{~N} \mathrm{ha}^{-1}$ & $28.56 \pm 0.84 \mathrm{ef}$ & $26.36 \pm 0.60 \mathrm{f}$ & $85.15 \pm 1.33 \mathrm{~d}$ & $86.09 \pm 1.05 \mathrm{~d}$ \\
$0.6 \mathrm{~kg} \mathrm{HA}+120 \mathrm{~kg} \mathrm{~N} \mathrm{ha}^{-1}$ & $31.22 \pm 0.83 \mathrm{~cd}$ & $29.04 \pm 0.80 \mathrm{de}$ & $92.65 \pm 1.42 \mathrm{c}$ & $93.70 \pm 1.41 \mathrm{c}$ \\
$1.2 \mathrm{~kg} \mathrm{HA}+120 \mathrm{~kg} \mathrm{~N} \mathrm{ha}^{-1}$ & $34.03 \pm 0.86 \mathrm{ab}$ & $32.19 \pm 0.54 \mathrm{bc}$ & $100.25 \pm 1.38 \mathrm{~b}$ & $101.98 \pm 0.64 \mathrm{~b}$ \\
$1.8 \mathrm{~kg} \mathrm{HA}+120 \mathrm{~kg} \mathrm{~N} \mathrm{ha}^{-1}$ & $35.60 \pm 0.50 \mathrm{a}$ & $34.25 \pm 0.36 \mathrm{ab}$ & $108.15 \pm 0.80 \mathrm{a}$ & $110.99 \pm 0.77 \mathrm{a}$ \\
\hline Means & $27.38 \mathrm{a}$ & $25.82 \mathrm{~b}$ & $80.27 \mathrm{~b}$ & $82.29 \mathrm{a}$ \\
\hline
\end{tabular}

Mean followed by same letters in a column do no differ significantly at $\mathrm{P} \leq 0.05$

\section{Discussion}

The application of humic acid and $\mathrm{N}$ caused significant increase in the plant height and leaf growth of both maize varieties. Maximum plant height, leaves plant ${ }^{-1}$, leaf area plant ${ }^{-1}$ and leaf area index was recorded in the Jalal variety of maize at $1.8 \mathrm{~kg} \mathrm{HA} \mathrm{ha}^{-1}$. The beneficial effect of humic acid on crop growth, number of leaves plant ${ }^{-1}$, leaf growth and its expansion in maize and other species has been reported by a number of plant researchers (Atiyeh et al., 2002; Daur and Bakhashwain, 2013). The possible explanation is the higher number of sinks produced, uptake of nutrients, and increased plant biomass due to humic acid application (El-Mekser et al., 2014). Likewise, the experimental plots treated with $\mathrm{N}$ fertilizer showed maximum plant height, number of leaves plant ${ }^{-1}$, leaf area plant $^{-1}$ and leaf area index in maize varieties Jalal and Iqbal. The stimulatory impact of $\mathrm{N}$ on plant height and leaf growth has been studied by many researchers (Onasanya et al., 2009; Inamullah et al., 2011; Kolari et al., 2014). The underlying reason is that $\mathrm{N}$ is an integral constituent of chlorophyll tissues of plant (Rizwan et al., 2003) which accelerated vegetative growth of the crop (Gokmen et al., 2001), leaf production and its size (Jasemi et al., 2013).

The nitrate reductase (NR) activity of leaves and net assimilation rate of both maize varieties significantly enhanced with the integration of humic acid and N. Higher NR activity of leaves and net assimilation rate was recorded in Iqbal as compared to Jalal variety of maize. The plants supplied with $1.8 \mathrm{~kg} \mathrm{HA} \mathrm{ha}^{-1}$ produced higher nitrate reductase (NR) activity and net assimilation rate. These findings are supported by Vaccaro et al. (2015) and Azeem et al. (2015) who found an acceleration in the NR activity and net assimilation rate of maize when they treated it with $5 \mathrm{mg}$ of humic acid 
liter $^{-1}$ of water and $1.5 \mathrm{~kg} \mathrm{HA} \mathrm{ha}^{-1}$, respectively. The possible explanation is the optimum nutrients availability, $\mathrm{H}^{+}$-ATPase synthesis (Canellas et al., 2013), and increased root length that in turn made better use of the available nutrients (Motaghi and Nejad, 2014). Similarly, the N nutrient activated the NR activity of leaves and net assimilation rate of both maize varieties against control plots of $\mathrm{N}$. As a result of higher $\mathrm{N}$ concentrations in the soil, higher nitrate accumulation occurred within the leaves of maize (Soleymani and Shahrajabian, 2013) with the activation of NR activity in leaves. It is because NR activity seemed to be directly related to nitrate or $\mathrm{N}$ availability within the plants (Vincentz et al., 1993; Cazetta et al., 2004). Habib et al. (2016) has also reported an increase in the net assimilation rate of maize due to $\mathrm{N}$ application. It is due to the beneficial effect of $\mathrm{N}$ on maize as it is a nitro positive crop (Gokmen et al., 2001) and responds well to $\mathrm{N}$ application under favourable soil moisture conditions. It is because humic acid has a crucial role in mineral nutrition and moisture retention capacity of the soil (Celik et al., 2011).

The integration of humic acid with $\mathrm{N}$ substantially increased the number of ears $\mathrm{m}^{-2}$ and ears plant ${ }^{-1}$ in maize varieties Jalal and Iqbal. The higher ear density was measured in Iqbal variety of maize at $1.8 \mathrm{~kg} \mathrm{HA} \mathrm{ha}^{-1}$. These results are in line with the findings of Iqbal (2014) who reported maximum productive tillers in wheat crop, treated with humic acid as compared to control. It could be due to the rapid penetration of humic acid in the plant cells, direct effect on chlorophyll content, acceleration of respiration, activation of growth enzymes, and indirectly through improved biological, physical and chemical conditions of the soil (Rajpar et al., 2011). The experimental application of $\mathrm{N}$ fertilizer increased the number of ears in maize varieties. The increase in number of ears with inorganic $\mathrm{N}$ fertilizer has been demonstrated by many researchers in maize crop (Hago and Sawi, 1995; Inamullah et al., 2011). The hidden reason is the provision of $\mathrm{N}$ nutrient in proper amount at reproductive growth stage of the crop (Shah et al., 2009) which accelerated the rate of photosynthesis (Kolari et al., 2014) and ear bearing capacity of maize crop (Bashir et al., 2012).

The ear length, thousand grain weight, grain yield, stover yield amd harvest index of both maize varieties significantly increased with the application of humic acid and N. The Iqbal variety of maize produced maximum ear length, thousand grain weight, grain yield and harvest with the application of $1.8 \mathrm{~kg} \mathrm{HA} \mathrm{ha}{ }^{-1}$ while the Jalal showed higher magnitude of stover yield with the same dose of humic acid. Various studies have shown the significant impact of humic acid on yield, yield components, stover yield and harvest index of maize crop (Ghorbani et al., 2010; Mohana et al., 2015). The reason is that humic acid creates an improvement in the physico-chemical properties of soil, and increased biomass production then occurs as a result of acceleration in plant biochemistry, physiology and productivity (Canellas and Olivares, 2014). Furthermore, N application accelerated the yield, yield components, stover yield and harvest index of maize varieties Jalal and Iqbal as compared to control plots of N (Sharifi and Taghizadeh, 2009). It is because $\mathrm{N}$ is a major plant nutrient and yield deciding factor for maize crop production (Manzoor et al., 2006) as it forms an integral component of protein and amino acids in the plants (Bakht et al., 2007). It enhanced nutrients uptake, assimilate production (Cirilo et al., 2009) and translocation of photosynthates from source to sink (Jena et al., 2015) which positively contributed to the increase in yield components of maize crop (Kaur et al., 2012).

The grain and stover $\mathrm{N}$ concentration of both maize varieties as well as their $\mathrm{N}$ uptake (grain $\mathrm{N}$ uptake, stover $\mathrm{N}$ uptake and total $\mathrm{N}$ uptake) considerably improved with the 
integration of humic acid and nitrogen. The plants of Iqbal variety treated with $1.8 \mathrm{~kg}$ $\mathrm{HA} \mathrm{ha}^{-1}$ showed higher grain and stover $\mathrm{N}$ concentration, grain $\mathrm{N}$ uptake and total $\mathrm{N}$ uptake. A number of plant researchers has described the significant impact of humic acid on enhancing the grain and stover $\mathrm{N}$ concentration of maize crop as well as its $\mathrm{N}$ uptake (Celik et al., 2010; Anees et al., 2016; Niaz et al., 2016). It is due to the stimulatory effect of humic acid on physical (Varanini et al., 1995), chemical and biological properties of soil (Khattak, 2004), nutrients concentrations, their availability, and transportation to the growing parts of maize plants (Celik et al., 2011). It is highly involved in the hormonal activities and enzymatic reactions within the plants (Nardi et al., 2002) and is responsible for the reduction and assimilation of $\mathrm{N}$ nutrient (Vaccaro et al., 2015). It provides particular bioactive molecules to the cell membranes of plants roots for $\mathrm{N}$ uptake (Canellas and Olivares, 2014). Likewise, higher $\mathrm{N}$ concentration, and $\mathrm{N}$ uptake were studied in the grain and stover of maize varieties Jalal and Iqbal with the use of $\mathrm{N}$ fertilizer because maize crop is an aggressive utilizer of available plant nutrients (Ayoola and Makinde, 2009). The possible explanation could be the increase in total $\mathrm{N}$ of soil, residual $\mathrm{N}$ of soil (Yang et al., 2007), mineralization of soil organic $\mathrm{N}$ (Li et al., 2003), amino acid formation (Almodares et al., 2009), an acceleration in physiological and bio-chemical processes of the plants (Rawal and Kuligod, 2014) that promoted N concentration and $\mathrm{N}$ uptake of maize varieties. These findings are supported by El-Hassan et al. (2014), Biswas and $\mathrm{Ma}$ (2014) and Niaz et al. (2016) who reported an increase in the grain and stover $\mathrm{N}$ concentration, and total $\mathrm{N}$ uptake of maize crop with applications of $\mathrm{N}$ fertilizer.

\section{Conclusion}

It was concluded that $1.8 \mathrm{~kg} \mathrm{HA} \mathrm{ha}^{-1}+120 \mathrm{~kg} \mathrm{~N}^{-1}$ resulted in maximum plant height, leaves plant ${ }^{-1}$, leaf area plant $^{-1}$, leaf area index, NR activity in leaves, net assimilation rate, ears $\mathrm{m}^{-2}$, ears plant ${ }^{-1}$, ear length, thousand grain weight, grain yield, stover yield, harvest index, grain $\mathrm{N}$ concentration, stover $\mathrm{N}$ concentration, grain $\mathrm{N}$ uptake, stover $\mathrm{N}$ uptake and total $\mathrm{N}$ uptake of maize varieties. However, the maize variety Iqbal out yielded than Jalal under the applied levels of humic acid with nitrogen. Therefore, against the sole use of inorganic $\mathrm{N}$, the local growers should use integration of $1.8 \mathrm{~kg} \mathrm{HA} \mathrm{ha}^{-1}+120 \mathrm{~kg} \mathrm{~N} \mathrm{ha}^{-1}$ along with maize variety Iqbal for obtaining higher yield of maize crop under the local environmental conditions. With this combination, it will be possible for local growers to accelerate the growth, physiology and yield of maize varieties with acceleration in the uptake of $\mathrm{N}$ nutrient which is often a limiting factor for crop production under the local semi-arid conditions. However, further research is needed to investigate the impact of higher levels of humic acids in integration with $\mathrm{N}$ on maize yield under the local agro-ecology.

Acknowledgements. The author and co-authors acknowledge Cereal Crops Research Institute, Pirsabak, Nowshera for providing seed material and technical help for conducting maize research experiments.

\section{REFERENCES}

[1] Abrol, Y. P., Adhya, T. K., Aneja, V. P., Raghuram, N., Pathak, H., Kulshrestha, U., Sharma, C., Singh, B. (eds.) (2017): The Indian Nitrogen Assessment: Sources of Reactive Nitrogen, Environmental and Climate Effects, Management Options, and Policies. Elsevier. 
[2] Abu-Grab, O. S., El-Kady, F. A., Darwich, A. A. (1997): Response of some maize cultivars to nitrogen fertilization under North and Middle Delta conditions. - Ann. of Agric. Sc., Moshtohor, Egypt. 35: 1-14.

[3] Afzal, N., Ahmad, S. (2009): Agricultural input use efficiency in Pakistan-key issues and reform areas. - Managing Natural Resources for Sustaining Future Agriculture Research Briefings 1: 1-12.

[4] Almodares, A., Hadi, M. R. (2009): Bioethanol production from sweet sorghum. - Afr. J. Agric. Res. 4: 772-780.

[5] Amandeep, K., Seema, B., Gill, G. K., Mahesh, K. (2012): Effect of nitrogen fertilizers on radiation use efficiency, crop growth and yield in some maize (Zea mays L.) genotypes. Maydica 57: 75-82.

[6] Amanullah. (2016): Rate and timing of nitrogen application influence partial factor productivity and agronomic NUE of maize (Zea mays L.) planted at low and high densities on calcareous soil in North West Pakistan. - J. Plant Nutr. 39: 683-690.

[7] Atiyeh, R. M., Lee, S., Edwards, C. A., Arancon, N. Q., Metzger, J. D. (2002): The influence of humic acids derived from earthworm-processed organic wastes on plant growth. - Bioresource Technol. 84: 7-14.

[8] Ayoola, O. T., Makinde, E. A. (2009): Maize growth, yield and soil nutrient changes with N-enriched organic fertilizers. - Afr. J. Food Agric. Nutr. Dev. 9: 580-592.

[9] Azam, F., Iqbal, M. M., Inayatullah, C., Malik, K. A. (2001): Technologies for sustainable agriculture. - Nuclear Institute for Agriculture and Biology, Faisalabad; p. 144.

[10] Azeem, K., Shah, S., Ahmad, N., Shah, S. T., Khan, F., Arafat, Y., Naz, F., Azeem, I., Ilyas, M. (2015): Physiological indices, biomass and economic yield of maize influenced by humic acid and nitrogen levels. - Basic Res. J. Agric. Sci. Rev. 4: 158-163.

[11] Bakht, J., Siddique, M. F., Shafi, M., Akbar, H., Tariq, M., Khan, N., Zubair, M., Yousef, M. (2007): Effect of planting methods and nitrogen levels on the yield and yield components of maize. - Sarhad J. Agric. 23: 253-259.

[12] Bashir, N., Malik, S. A., Mahmood, S., Mahmood-ul-Hassan, Athar, H. R., Athar, M. (2012): Influence of urea application on growth, yield and mineral uptake in two corn (Zea mays L.) cultivars. - Afr. J. Biotechnol. 11: 10494-10503.

[13] Beadle, C. L. (1993): Growth analysis. In photosynthesis and production in a changing environment. - Springer Dordrecht; p. 36-46.

[14] Biswas, D. K., Ma, B. L. (2016): Effect of nitrogen rate and fertilizer nitrogen source on physiology, yield, grain quality, and nitrogen use efficiency in corn. - Canadian J. Plant Sci. 96: 392-403.

[15] Bremner, J. M., Mulvaney, C. S. (1982): Nitrogen-total. Methods of soil analysis. Part 2. Chemical and microbiological properties; p. 595-624.

[16] Camara, K. M., Payne, W. A., Rasmussen, P. E. (2003): Long-term effects of tillage, nitrogen, and rainfall on winter wheat yields in the Pacific Northwest. - Agron. J. 95: 828835.

[17] Canellas, L. P., Balmori, D. M., Médici, L. O., Aguiar, N. O., Campostrini, E., Rosa, R. C., Façanha, A. R., Olivares, F. L. (2013): A combination of humic substances and herbaspirillum seropedicae inoculation enhances the growth of maize (Zea mays L.). Plant Soil. 366: 119-132.

[18] Canellas, L. P., Olivares, F. L. (2014): Physiological responses to humic substances as plant growth promoter. - Chem. Biol.Technol. Agric. 1:3.

[19] Cazetta, J. O., Villela, L. C. V. (2004): Nitrate reductase activity in leaves and stems of tanner grass (Brachiaria radicans Napper). - Sci. Agric. 61: 640-648.

[20] Celik, H., Katkat, A. V., Așik, B. B., Turan, M. A. (2010): Effects of humus on growth and nutrient uptake of maize under saline and calcareous soil conditions. - Agric. 97: 15-22.

[21] Celik, H., Katkat, A. V., Aşik, B. B., Turan, M. A. (2011): Effect of foliar-applied humic acid to dry weight and mineral nutrient uptake of maize under calcareous soil conditions. Commun. Soil Sci. Plant Anal. 42: 29-38. 
[22] Cirilo, A. G., Dardanelli, J., Balzarini, M., Andrade, F. H., Cantarero, M., Luque, S., Pedrol, H. M. (2009): Morphophysiological traits associated with maize adaptations to environments differing in nitrogen availability. - Field Crop Res. 113: 116-124.

[23] Daur, I., Bakhashwain, A. A. (2013): Effect of humic acid on growth and quality of maize fodder production. - Pak. J. Bot. 45: 21-25.

[24] Derby, N. E., Casey, F. X. M., Knighton, R. E., Steel, D. D. (2004): Midseason nitrogen fertility management for corn based on weather and yield prediction. - Agron. J. 96: 494501.

[25] Dong, H., Zhang, G., Jiang, H., Yu, B., Chapman, L. R., Lucas, C. R., Fields, M. W. (2006): Microbial diversity in sediments of saline Qinghai Lake, China: linking geochemical controls to microbial ecology. - Microb. Ecol. 51: 65-82.

[26] Dong, L., Cordova-Kreylos, A. L., Yang, J., Yuan, H., Scow, K. M. (2009): Humic acids buffer the effects of urea on soil ammonia oxidizers and potential nitrification. - Soil Biol. Biochem. 41: 1612-1621.

[27] El-Hassan, W. H. A., Hafez, E. M., Ghareib, A. A. A., Freeg, M. R., Seleiman, M. F. (2014): Impact of nitrogen fertilization and irrigation on water utilization efficiency, $\mathrm{N}$ accumulation, growth and yields of Zea mays L. - J. Food, Agric. Environ. 12: 217-222.

[28] El-Mekser, H., Mohamed, Z. E. O. M., Ali, M. A. M. (2014): Influence of humic acid and some micronutrients on yellow corn yield and quality. - World Appl. Sci. J. 32: 1-11.

[29] Ghorbani, S., Khazaei, H. R., Kafi, M., Bannayan, A. M. (2010): Effect of humic acid application with irrigation water on yield and yield components of corn (Zea mays L.). - J. Agroecol. 2: 111-118.

[30] Gokmen, S. O., Sencar, O., Sakin, M. A. (2001): Response of popcorn (Zea mays L. everta) to nitrogen rates and plant densities. - Turk. J. Agric. For. 25: 15-23.

[31] Government of Pakistan. (2016): Pakistan Economic Survey 2014-15. - Finance division, Economic Advisor's Wing, Islamabad, Pakistan; p. 26.

[32] Grassini, P., Thorburn, J., Burr, C., Cassman, K. G. (2011): High-yield irrigated maize in the Western U.S. Corn Belt: I. On-farm yield, yield potential, and impact of agronomic practices. - Field Crops Res. 120: 142-150.

[33] Habib, M. D., Asif, M., Aziz, M., Ali, A., Ashraf, M., Mahmood, A., Javaid, M. M. (2016): Growth performance of spring maize and soil fertility status as influenced by nutrient sources. - Int. J. Agric. Appl. Sci. 4: 35-41.

[34] Hago, T. E. M., Sawi, S. M. A. (1995): The effects of nitrogen and phosphorus on yield and yield components of maize (Zea mays L.) under irrigation. - J. Agric. Sci. 3: 22-31.

[35] Iqbal, B. (2016): Response of wheat crop to humic acid and nitrogen levels. - EC Agric. 3: 558-565.

[36] Jasemi, M., Darab, F., Naser, R. (2013): Effect of planting date and nitrogen fertilizer application on grain yield and yield components in maize. - Am-Eurasian J. Agric. Environ. Sci. 13: 914-919.

[37] Jena, N., Vani, K. P., Rao, V. P., Sankar, A. S. (2015): Effect of nitrogen and phosphorus fertilizers on growth and yield of quality protein maize (QPM). - Int. J. Sci. Res. 4: 18391840.

[38] Kaur, A. (2012): Physiological basis of nitrogen use efficiency in maize at various rates of applied nitrogen. - Ph.D. dissertation, Punjab Agricultural University, Ludhiana.

[39] Khan, H. Z., Iqbal, S., Akbar, N., Saleem, M. F., Iqbal, A. (2013): Integrated management of different nitrogen sources for maize production. - Pak. J. Agric. Sci. 50: 55-61.

[40] Khattak, M. K. (2004): Influence of various tillage practices on yield of wheat-maize under clay loam soil condition. - Sarhad J. Agric. 20: 429-443.

[41] Kolari, F., Bazregar, A., Bakhtiari, S. (2014): Phenology, growth aspects and yield of maize affected by defoliation rate and applying nitrogen and vermicompost. - Indian J. Fundamental Appl. Life Sci. 4: 61-71. 
[42] Lewis, O. A. M., James, D. M., Hewitt, E. J. (1982): Nitrogen assimilation in barley (Hordeum vulgare L.) in response to nitrate and ammonium nutrition. - Ann. Bot. 49: 3949.

[43] Li, H., Han, Y., Cai, Z. (2003): Nitrogen mineralization in paddy soils of the Taihu region of China under anaerobic conditions: dynamics and model fitting. - Geoderma 115: 161175.

[44] Maheswari, M., Murthy, A. N. G., Shanker, A. K. (2017): Nitrogen nutrition in crops and its importance in crop quality. - In: The Indian nitrogen assessment: sources of reactive nitrogen, environmental and climate effects, management options, and policies; p. 175.

[45] Moghadam, H. T., Khamene, M. K., Zahedi, H. (2015): Effect of humic acid foliar application on growth and quantity of corn in irrigation withholding at different growth stages. - Maydica 59: 124-128.

[46] Mohana, A. A., Suleiman, M. M., Khedr, W. S. (2015): Effect of humic acid and rates of nitrogen fertilizer on yield and yield components of corn (Zea mays L.). - Jordan Journal of Agricultural Sciences 11: 229-241.

[47] Mohd, T., Osumanu, H. A., Nik, M. (2009): Effect of mixing urea with humic acid and acid sulphate soil on ammonia loss, exchangeable ammonium and available nitrate. - Am. J. Environ. Sci. 5: 588-591.

[48] Motaghi, S., Nejad, T. S. (2014): The effect of different levels of humic acid and potassium fertilizer on physiological indices of growth. - Int. J. Biosci. 5: 99-105.

[49] Nardi, S., Pizzeghello, D., Muscolo, A., Vianello, A. (2002): Physiological effects of humic substances on higher plants. - Soil Biol. Biochem. 34: 1527-1536.

[50] Niaz, A., Yaseen, M., Shakar, M., Sultana, S., Ehsan, M., Nazarat, A. (2016): Maize production and nitrogen use efficiency in response to nitrogen application with and without humic acid. - J. Anim Plant Sci. 26: 1641-1651.

[51] Onasanya, R. O., Aiyelari, O. P., Onasanya, A., Oikeh, S., Nwilene, F. E., Oyelakin, O. O. (2009): Growth and yield response of maize (Zea mays L.) to different rates of nitrogen and phosphorus fertilizers in southern Nigeria. - World J. Agric. Sci. 5: 400-407.

[52] Rajpar, I., Bhatti, M. B., Zia-ul-Hassan, Shah, A. N., Tunio, S. D. (2011): Humic acid improves growth, yield and oil content of Brassica compestris L. - Pak. J. Agric. Agricul. Eng. Vet. Sci. 27: 125-133.

[53] Rawal, R., Kuligod, V. B. (2014): Influence of graded doses of nitrogen on nutrient uptake and grain yield of maize (Zea mays L.) under varying levels of soil salinity. - Karnataka J. Agric. Sci. 27: 22-24.

[54] Rizwan, M., Maqsood, M., Rafiq, M., Saeed, M., Ali, A. (2003): Maize (Zea mays L.) response to split application of nitrogen. - Int. J. Agric. Biol. 5: 19-21.

[55] Saruhan, V., Kusvuran, A., Kokten, K. (2011): The effect of different replications of humic acid fertilization on yield performances of common vetch (Vicia sativa L.). - Afr. J. Biotechnol. 10: 5587-5592.

[56] Shah, S. T. H., Zamir, M. S. I., Waseem, M., Ali, A., Tahir, M., Khalid, W. B. (2009): Growth and yield response of maize (Zea mays L.) to organic and inorganic sources of nitrogen. - Pak. J. Life Soc. Sci. 7: 108-111.

[57] Sharifi, R. S., Taghizadeh, R. (2009): Response of maize (Zea mays L.) cultivars to different levels of nitrogen fertilizer. - J. Food, Agri. Environ. 7: 518-521.

[58] Soleymani, A., Shahrajabian, M. H. (2012): The effects of nitrogen fertilizer on ash, nitrate, organic carbon, protein and total yield of forage maize in semi-arid region of Iran. - Res. on Crops 13: 1030-1034.

[59] Steel, R. G. D., Torrie, J. H. (1997): Principles and procedures of statistics. $-2^{\text {nd }}$ ed. McGraw Hill Book Company, Inc: New York.

[60] Tolessa, D., Du Preez, C. C., Ceronio, G. M. (2007): Comparison of maize genotypes for grain yield, nitrogen uptake and use efficiency in western Ethiopia. - S. Afr. J. Plant Soil 24: 70-76. 
[61] Traversa, A., Loffredo, E., Gattullo, C. E., Palazzo, A. J., Bashore, T. L., Senesi, N. (2014): Comparative evaluation of compost humic acids and their effects on the germination of switchgrass (Panicum vigatum L.). - J. Soil Sediment 14: 432-440.

[62] Turkmen, O., Dursun, A., Turan, M., Erdinc, C. (2004): Calcium and humic acid affect seed germination, growth, and nutrient content of tomato (Lycopersicon esculentum L.) seedlings under saline soil conditions. - Acta Agriculturae Scandinavica 54: 168-174.

[63] Vaccaro, S., Ertani, A., Nebbioso, A., Muscolo, A., Quaggiotti, S., Piccolo, A., Nardi, S. (2015): Humic substances stimulate maize nitrogen assimilation and amino acid metabolism at physiological and molecular level. - Chem. Biol. Technol. Agric. 2:5.

[64] Varanini, Z., Pinton, R., Behnke, H. D., Luttge, U., Esser, K., Kadereit, J. W., Runge, M. (1995): Humic substances and plant nutrition. Progress in Botany: Structural botany, physiology, genetics and taxonomy. - Geobotany 56: 97-117.

[65] Vincentz, M., Moureaux, T., Leydecker, M. T., Vaucheret, H., Caboche, M. (1993): Regulation of nitrate and nitrite reductase expression in Nicotiana plumbaginifolia leaves by nitrogen and carbon metabolites. - Plant J. 3: 315.

[66] Yang, J. Y., Huffman, E. C., De Jong, R., Kirkwood, V., MacDonald, K. B., Drury, C. F. (2007): Residual soil nitrogen in soil landscapes of Canada as affected by land use practices and agricultural policy scenarios. - Land Use Policy 24: 89-99.

[67] Yousaf, M., Li, X., Zhang, Z., Ren, T., Cong, R., Ata-Ul-Karim, S. T., Fahad, S., Shah, A. N., Lu, J. (2016): Nitrogen fertilizer management for enhancing crop productivity and nitrogen use efficiency in rice-oil seed rape rotation system in china. - Front. Plant Sci. $7: 1496$. 